\title{
Post-Transfusion Occult Hepatitis B (OBI): A Global Challenge for Blood Recipients and Health Authorities
}

\author{
Mohammad Kazemi Arababadi ${ }^{1^{*}}$, Gholamhossein Hassanshahi ${ }^{1,2}$, Ali Akbar Pourfathol- \\ lah $^{3}$, Ebrahim Rezazadeh Zarandi ${ }^{1,2}$, Derek Kennedy ${ }^{4}$ \\ ${ }^{1}$ Department of Microbiology, Hematology and Immunology, Faculty of Medicine, Rafsanjan University of Medical Sciences, Rafsanjan, IR Iran \\ ${ }^{2}$ Molecular Medicine Research Center, Rafsanjan University of Medical Sciences, Rafsanjan, IR Iran \\ ${ }^{3}$ Department of Immunology, School of Medical Sciences, Tarbiat Modares University, Tehran, IR Iran \\ ${ }^{4}$ School of Biomolecular and Physical Science, Eskitis Institute for Cell and Molecular Therapies, Griffith University Nathan, Queensland, Australia
}

\section{A R T I C L E I N F O}

Article Type:

Review Article

Article history:

Received:10 Feb 2011

Revised: 12 Apr 2011

Accepted: 26 Apr 2011

\section{Keywords:}

Hepatitis B

Transfusion

Epidemiology

\section{A B S T R A C T}

Hepatitis B is one of the most frequent post-transfusion infections. Occult hepatitis B infection (OBI) is a form of hepatitis B infection in which, despite the presence of HBVDNA in the serum and hepatocytes of the carrier, HBsAg is absent. In addition to the risk of transmission through the transfusion of infected blood, reactivation of hepatitis B in OBI patients and recipients of their blood can lead to cirrhosis, hepatic cancer, and reactivation of viral replication in the carrier. Therefore, effective assays to assess and screen for OBI in blood donors are of paramount importance and require urgent attention. Recently, several investigations in various regions of Iran have reported OBI in blood donors. In response, there has been a drive to apply more specific, sensitive, and accurate methods for the detection of HBV, which should become an obligatory screening process for all blood transfusion services. In this review, we address the progression of occult hepatitis B and the common problems associated with occult hepatitis B worldwide. Finally, we reflect on the research and screening that is being performed in Iran to deal with this problem.

๑ 2011 Kowsar M.P.Co. All rights reserved.

- Implication for health policy/practice/research/medical education:

Occult HBV infection (OBI) is a potential risk factor for post transfusion hepatitis B. Based on recent reports, this review aims to present the current status of OBI prevalence among worldwide blood donors, common problems associated with OBI as well as useful tests for HBV screening.

- Please cite this paper as:

Kazemi Arababadi M, Hassanshahi G, Pourfathollah AA, Rezazadeh Zarandi E, Kennedy D. Post-Transfusion Occult Hepatitis B (OBI): A Global Challenge for Blood Recipients and Health Authorities. Hepat Mon. 2011;11(9):714-8. DOI: 10.5812/kowsar.1735143X.694

\section{Background}

Hepatitis B Virus (HBV) is one of the most frequent and detrimental causes of liver infection in humans (1). The most commonly noted symptoms of HBV-related hepa-

* Corresponding author at: Mohammad Kazemi Arababadi, Department of Microbiology, Hematology and Immunology, Faculty of Medicine, Rafsanjan University of Medical Sciences, Rafsanjan, IR Iran. Tel: +98-3915234003-5, Fax: +98-3915225209. E-mail: dr.kazemi@rums.ac.ir

DOI:10.5812/kowsar.1735143X.694

Copyright $\odot 2011$, BRCGL, Published by Kowsar M.P.Co. All rights reserved. titis are jaundice, orangeade skin, and ophthalmia-protein, which is accompanied by increased bilirubin that results from the destruction of the liver cells that would normally process these proteins (2). According to the latest reports, more than 2 billion people worldwide have serological markers of HBV, and more than 360 million of these are suffering from chronic HBV infection (3). To decrease the risk of post-transfusion hepatitis (PTH) in the Iranian blood transfusion service (IBTS), all blood units and blood components are screened for HBsAg using ELISA (4). Despite rigorous screening across the 
nation using modern equipment and internationally accepted screening methods to detect HBV, cases of PTH are still reported (5). Hepatitis B infection is categorized into 5 clinical forms: (1) acute, (2) chronic, (3) fulminate, (4) asymptomatic, and (5) occult HBV infection (OBI) (6). OBI is a form of long-term HBV infection; however, the clinical symptoms are undefined and differ from those of the previous described forms of HBV (7). OBI differs from asymptomatic HBV infection in that although carriers are serologically negative for HBsAg, HBV-DNA is present in the serum (8). Due to its particular properties, OBI is not detected by the common HBV assays, and it is thus capable of creating significant problems for blood transfusion services (9). Therefore, in this review article, we consider different aspects of $\mathrm{OBI}$, such as its prevalence in Iran and the throughout world, and assess the value of some serological diagnostic methods regularly used for OBI detection.

\section{Clinical Symptoms Associated with OBI}

Reactivation or low-level activity of hepatitis B virus in patients with OBI has been shown to lead to the development of other clinical disorders. Therefore, several research groups have focused on the correlation between hepatitis B infection and the onset of related clinical disorders. The clinical symptoms of OBI are mainly categorized into the following groups:

\subsection{OBI and Chronic Liver Disease}

It is well established that individuals who survive acute hepatitis B infection may shift to OBI (10), and despite regular examinations and clinical follow up for several years thereafter, mild necrotic inflammation can be observed in the liver tissue (10). It could be speculated that, although OBI does not exhibit clinically distinct symptoms, the low-level viral replication and viral gene expression can initiate an immune response against hepatocytes, which is sufficient to generate liver necrosis (10). Moreover, it has also been suggested that the severity of liver injury increases when chronic HCV carriers are coinfected with trace HBV particles by way of OBI (11-13), and that fibrosis and cirrhosis may occur in conjunction with OBI (14). In general, it appears that any liver damage in the presence of residual HBV or OBI could initiate an immune response that can result in severe liver damage.

\subsection{OBI and Hepatocellular Carcinoma}

OBI is a possible risk factor for hepatocellular carcinoma (HCC) $(15,16)$. The following 3 situations have been well established as important in transducing OBI to induce HCC:1) Merging of the HBV genome with a patient's chromosome, 2) Long-term inflammatory necrosis during OBI, and 3) cirrhosis that subsequently develops into OBI (16). The exact steps required for this progression are not clear, and additional studies are required to draw a definitive conclusion regarding the effect of OBI in in- ducing HCC.

\section{Transmission and Activation of $\mathrm{OBI}$}

OBI is considered a high-risk factor for both blood donors (due to the potential risk of hepatitis B reactivation) and recipients (due to the risk of infection transmission), which is described below.

\subsection{Transmission of Infection}

All OBI carriers are predisposed to transmitting HBV via blood transfusion and organ transplantation, especially liver allograft transplantation $(17,18)$. However, it should be mentioned, that as a result of the development of screening methods and programs for blood transfusion services worldwide, the incidence of PTH has decreased significantly. Despite these measures, some countries are still struggling with HBV transmission through these mechanisms (17). For example, in the Asian region, several cases of PTH have been reported in India and Taiwan $(19,20)$. OBI transmission via organ transplantation has also been reported (18). The risk of HBV transmission via OBI patients is enhanced in hepatic allograft engraftment since hepatocytes are the main source of HBV (21). The risk of PTH from OBI patients is lower in heart (22) and renal transplantation (23), while bone marrow transplantation carries the lowest risk of PTH (24). Some studies have reported that blood containing anti-HBc and anti-HBs, does not appear to transmit HBV components, even though the viral load ranges between 20 and 500 $\mathrm{IU} / \mathrm{mL}$ (25). For example, in a recent look-back study, 49 blood transfusion recipients were traced to 10 donors with OBI. However, the results showed that only 1 recipient had an HBV strain with 95\% sequence homology to that of the donor (25), suggesting that the majority of transfusion patients that subsequently developed hepatitis B did not contract the disease via the OBI donor. Furthermore, they reported that after inoculation of 2 OBI donor serum samples into 4 chimeric mice, only 1 mouse subsequently had measurable HBV DNA (25). This controversy needs further studies to be resolved.

\subsection{OBI Reactivation}

The unknown mechanisms that appear to suppress the replication and gene expression of $\mathrm{HBV}$, along with the inability of the immune system to facilitate complete clearance of HBV are the primary reasons OBI becomes established (26). It would appear that under any condition that leads to immune deficiency, such as AIDS or chemotherapy, HBV can be reactivated and commence a program of viral replication and gene expression that is subsequently followed by an active or fulminant form of hepatitis B infection $(27,28)$. The functional reactivation of HBV eventually leads to a systematic immune response of memory T cells against infected hepatocytes, which progresses to liver inflammation and viral hepatitis (28). In addition to the abovementioned diseases and treatments that lead to suppression of the immune system, some background disorders, including hemato- 
logical malignancies (29) and allograft transplantations of bone marrow and other organs $(30,31)$, can cause OBI reactivation.

\section{Prevalence of OBI among National and International Blood Donors}

Published evidence indicates that OBI is spread widely throughout the world, and patients co-infected with chronic hepatitis $C$ infection are at increased risk (10, 32). Moreover, investigators believe that several other factors, in addition to chronic HCV, may also contribute to the prevalence of OBI, including geographical, epidemiological, and ethnic factors (33). For instance, we have not observed any cases of OBI among HCV-infected thalassemia and hemodialysis patients in the Kerman province of Iran $(33,34)$. In addition to HCV-infected patients, $45 \%$ of intravenous narcotic users (35) and 51\% of patients with hemophilia (36) have been shown to suffer from OBI. A wide range of OBI (0-36\%) has been reported in hemodialysis patients $(11,13,34)$. Altogether, these data indicate that the prevalence of OBI among blood donors varies from country to country in different parts of the world. For example, in the European countries of Poland, Italy, Spain, and Germany, OBI prevalence rates of $0.006 \%$, $0.22 \%, 0.05 \%$, and $0.0006 \%$, respectively, have been report- ed (37) (Table 1). Our previous results in Isfahan showed that $9 \%$ of HBsAg blood donors were HBV-DNA ${ }^{+}$, while $1.43 \%$ of Rafsanjan blood donors were HBsAg/HBV-DNA ${ }^{+}$ (38). Behbahani et al. and Amini et al. reported that 0.8\% and $0.15 \%$ of HBsAg blood donors in Shiraz and Tehran, respectively, were $\mathrm{HBV}-\mathrm{DNA}^{+}(39,40)$. As described above, most studies evaluating OBI have been performed in blood donors, and only a small number of studies have evaluated OBI in the general population. For example, Song et al. reported that the rate of OBI in the general adult population of Korea was 0.7\% (41). Raimondo and colleagues researched OBI in individuals without hepatic disease who underwent liver resection or needle biopsy during abdominal surgery (10). They showed that $1 / 6$ of the Italian general population is a carrier of occult HBV infection (10). In addition, Sharifi et al. reported that 3 out of 110 anti-HBc-positive family members of patients with acute or chronic HBV infection suffer from OBI (42). Although there is minimal data available regarding the prevalence of OBI in the general population, based on the results of Song et al. (41) and Sharifi et al. (42), it seems that the prevalence of OBI in the general population is higher than that in blood donors. This may be related to the fact that blood donors are screened for HBV infection; therefore, it is detected as soon as possible and infected individuals are excluded from donation. In addi-

Table 1. Prevalence of OBI in Iran and Several Other Countries. The Table Shows the Occurrence of OBI in Blood Donors in Iranian Compared to that in Blood Donors in Other Counties. The Results Were Obtained from Several Research Groups, and the Appropriate References Are Cited.

\begin{tabular}{|c|c|c|c|}
\hline & $\begin{array}{l}\text { OBI Condition, } \\
\text { No. }\end{array}$ & $\begin{array}{l}\text { Total, } \\
\text { No. }\end{array}$ & $\begin{array}{l}\text { OBI, } \\
\%\end{array}$ \\
\hline \multicolumn{4}{|l|}{ Iran } \\
\hline Tehran (40) & 3 & 2,000 & 0.15 \\
\hline Rafsanjan (43) & 4 & 270 & 1.48 \\
\hline Shiraz (39) & 16 & 2,000 & 0.8 \\
\hline Isfahan (43) & 5 & 545 & 0.9 \\
\hline Rafsanjan (4) & 57 & 3,700 & 1.54 \\
\hline Zahedan (42) & 3 & 110 & 2.72 \\
\hline \multicolumn{4}{|l|}{ Poland } \\
\hline $\begin{array}{l}\text { Totals from different } \\
\text { geographical regions (37) }\end{array}$ & 17 & 250,191 & 0.006 \\
\hline \multicolumn{4}{|l|}{ Italy } \\
\hline Rome (37) & 8 & 35,016 & 0.02 \\
\hline Turin (37) & 18 & 236,708 & 0.007 \\
\hline Messina (10) & 16 & 98 & 16.3 \\
\hline \multicolumn{4}{|l|}{ Spain } \\
\hline Barcelona (37) & 8 & 15,545 & 0.05 \\
\hline Valencia (37) & 12 & 117,829 & 0.01 \\
\hline \multicolumn{4}{|l|}{ Germany } \\
\hline Frankfort (37) & 7 & $1,348,759$ & 0.0006 \\
\hline \multicolumn{4}{|l|}{ Mexican } \\
\hline Mexico city (51) & 17 & 158 & 0.006 \\
\hline Oman (52) & 0 & 200 & 0.0 \\
\hline \multicolumn{4}{|l|}{ Brazil } \\
\hline Brasilia (53) & 5 & 150 & 3.3 \\
\hline \multicolumn{4}{|l|}{ South Korea } \\
\hline Seoul (41) & 7 & 1,047 & 0.7 \\
\hline
\end{tabular}


tion, it seems that the prevalence of OBI in blood donors has a regional variance, not only internationally but also nationally. In Iran, the infection rate ranges from $0.8 \%$ in Shiraz to $2.72 \%$ in Zahedan (Table 1). This national variance may be related to the fact that the prevalence of HBV infection is highest in Southeastern Iran (41), which has led to increased incidence of OBI, or perhaps the blood donors evaluated in our studies were more expansive than in other reports $(4,43)$.

\section{Diagnosis of $\mathrm{OBI}$}

Obviously, the best method for the diagnosis of OBI is the examination of liver cells for the presence of HBVDNA (10). However, due to the invasive nature of biopsy and the possibility of undesirable injuries to the liver during preparation, most current OBI studies are performed on peripheral blood samples (10). A patient who is $\mathrm{HBsAg} / \mathrm{HBV}-\mathrm{DNA}^{+}$and entirely free of any clinical symptoms of hepatitis and jaundice is considered to have OBI (44). Clinical researchers worldwide have paid special attention to the application of hepatitis B core antibodies (HBc-Ab; also referred to as anti-HBc) for the rejection of at-risk blood units and blood components in blood transfusion services (1). HBc-Ab is well documented as the first detectable circulating antibody against HBV, which has the highest titer among antibodies (1). Therefore, detection of this antibody is a useful confirmatory tool that can be used in parallel with HBsAg (44). In some countries, including the USA and Japan, parallel screening for HBsAg and $\mathrm{HBc}-\mathrm{Ab}$ is performed in all donor samples $(17,45)$; in contrast, in India, HBc-Ab is not in the screening program for blood transfusions (46). A wide variety of studies have examined the detection of this antibody among Iranian volunteer blood donors. Our previous studies in Esfahan (47) and Rafsanjan blood donors (4, 43) showed HBc-Ab frequencies of $8 \%$ and $5.18 \%-9.5 \%$, respectively. Other research groups have reported the rates of HBc-Ab antibody in different cities of Iran, including $6.5 \%, 11.5 \%, 4.8 \%$, and $4.8 \%$ in Shiraz, Tehran, Boroojerd, and Khoramabad, respectively $(39,40,48)$. The reasons for the discrepancies in these results from different teams of investigators in various parts of the world (Table 1) could likely be categorized as follows:

1. Different sample sizes in the studies

2. The use of different laboratory equipment and measurement kits with different specificities and sensitivities

3. Different racial, ethnic, and genetic backgrounds, which can often affect the humoral immune response to HBV, leading to differences in HBc-Ab production (49, 50)

In conclusion, according to the abovementioned reports, it seems that the directors of Iranian blood transfusion services are in the best position to decide (based on scientific and economic criteria) how to implement regular screening for $\mathrm{HBc}-\mathrm{Ab}$ in donated blood units with a view to reduce the risk of post-transfusion and post-surgery transmission of HBV.

\section{Conclusion}

Due to the high prevalence of HBc-Ab and OBI in Iranian blood donors, the authors of this article suggest a screening program for HBc-Ab with the use of commercial kits. We also propose the use of PCR-based screening programs for diagnosis of OBI in all IBTS.

\section{Acknowledgements}

The authors of this article would like to thank Dr. Jafarzadeh, the head of the Immunology and Hematology Department at the Rafsanjan University of Medical Sciences for his warm support and assistance in the preparation of this review. This project was supported by a grant from the Rafsanjan University of Medical Sciences.

\section{Financial Disclosure}

None declared.

\section{Funding/Support}

This project was financially supported by Rafsanjan University of Medical Sciences. The authors do not have a financial relationship with any commercial entity that has an interest in the subject of this manuscript.

\section{References}

1. Gerlich WH, Bremer C, Saniewski M, Schuttler CG, Wend UC, Willems WR, et al. Occult hepatitis B virus infection: detection and significance. Dig Dis. 2010;28(1):116-25.

2. de Oliveira FA, dos Reis MA, Castro EC, da Cunha SF, Teixeira Vd Vde P. [Infeccious diseases as causes of death in autopsied elderly]. Rev Soc Bras Med Trop. 2004;37(1):33-6.

3. Valsamakis A. Molecular testing in the diagnosis and management of chronic hepatitis B. Clin Microbiol Rev. 2007;20(3):426-39, table of contents.

4. Arababadi MK, Pourfathollah AA, Jafarzadeh A, Hassanshahi G, Rezvani ME. Association of exon 9 but not intron 8 VDR polymorphisms with occult HBV infection in south-eastern Iranian patients. J Gastroenterol Hepatol. 2010;25(1):90-3.

5. Candotti D, Allain JP. Transfusion-transmitted hepatitis B virus infection. J Hepatol. 2009;51(4):798-809.

6. Song le H, Xuan NT, Toan NL, Binh VQ, Boldt AB, Kremsner PG, et al. Association of two variants of the interferon-alpha receptor-1 gene with the presentation of hepatitis B virus infection. Eur Cytokine Netw. 2008;19(4):204-10.

7. Carreno V, Bartolome J, Castillo I, Quiroga JA. Occult hepatitis B virus and hepatitis C virus infections.RevMedVirol.2008;18(3):13957.

8. Arababadi MK, Pourfathollah AA, Jafarzadeh A, Hassanshahi G, Mohit M, Hajghani M. Peripheral blood NK cells CCR5 expression in Iranian patients with occult hepatitis B infection. Lab Medicine. 2010;41(1):19-22.

9. Arababadi MK, Pourfathollah AA, Jafarzadeh A, Hassanshahi G, Mohit M, Hajghani M, et al. Peripheral Blood CD8+ T Cells CCR5 Expression and Its $\Delta 32$ Mutation in Iranian Patients with Occult Hepatitis B Infections. Lab Medicine. 2010;41(4):226-30.

10. Raimondo G, Navarra G, Mondello S, Costantino L, Colloredo G, Cucinotta E, et al. Occult hepatitis B virus in liver tissue of individuals without hepatic disease. J Hepatol. 2008;48(5):743-6.

11. Siagris D, Christofidou M, Triga K, Pagoni N, Theocharis GJ, Goumenos D, et al. Occult hepatitis B virus infection in hemodialysis patients with chronic HCV infection. J Nephrol. 2006;19(3):327-33. 
12. Kanbay M, Gur G, Akcay A, Selcuk H, Yilmaz U, Arslan H, et al Is hepatitis $\mathrm{C}$ virus positivity a contributing factor to occult hepatitis B virus infection in hemodialysis patients? Dig Dis Sci. 2006;51(11):1962-6.

13. Goral V, Ozkul H, Tekes S, Sit D, Kadiroglu AK. Prevalence of occult HBV infection in haemodialysis patients with chronic HCV. World J Gastroenterol. 2006;12(21):3420-4.

14. Adachi S, Shibuya A, Miura Y, Takeuchi A, Nakazawa T, Saigenji K Impact of occult hepatitis B virus infection and prior hepatitis $B$ virus infection on development of hepatocellular carcinoma in patients with liver cirrhosis due to hepatitis C virus. Scand J Gastroenterol. 2008;43(7):849-56.

15. Brechot C, Thiers V, Kremsdorf D, Nalpas B, Pol S, PaterliniBrechot P. Persistent hepatitis B virus infection in subjects without hepatitis B surface antigen: clinically significant or purely “occult"? Hepatology. 2001;34(1):194-203.

16. Torbenson M, Thomas DL. Occult hepatitis B. Lancet Infect Dis. 2002;2(8):479-86.

17. Hollinger FB, Sood G. Occult hepatitis B virus infection: a covert operation.J Viral Hepat. 2010;17(1):1-15.

18. Shouval D. What is the clinical significance of the high prevalence of occult hepatitis B in US liver transplant patients with chronic hepatitis C? Liver Transpl. 2008;14(4):418-9.

19. Liu CJ, Lo SC, Kao JH, Tseng PT, Lai MY, Ni YH, et al. Transmission of occult hepatitis B virus by transfusion to adult and pediatric recipients in Taiwan.J Hepatol. 2006;44(1):39-46.

20. Saraswat S, Banerjee K, Chaudhury N, Mahant T, Khandekar P, Gupta RK, et al. Post-transfusion hepatitis type B following multiple transfusions of HBsAg-negative blood. J Hepatol. 1996;25(5):639-43.

21. Takemura N, Sugawara Y, Tamura S, Makuuchi M. Liver transplantation using hepatitis B core antibody-positive grafts: review and university of Tokyo experience. Dig Dis Sci. 2007:52(10):2472-7.

22. Wachs ME, Amend WJ, Ascher NL, Bretan PN, Emond J, Lake JR, etal. The risk of transmission of hepatitis B from $\operatorname{HBsAg}(-), \operatorname{HBcAb}(+)$, HBIgM(-) organ donors. Transplantation. 1995;59(2):230-4.

23. De Feo TM, Poli F, Mozzi F, Moretti MP, Scalamogna M. Risk of transmission of hepatitis B virus from anti-HBC positive cadaveric organ donors: a collaborative study. Transplant Proc. 2005;37(2):1238-9.

24. Strasser SI, McDonald GB. Hepatitis viruses and hematopoietic cell transplantation: A guide to patient and donor management. Blood.1999;93(4):1127-36.

25. Yuen MF, Wong DK, Lee CK, Tanaka Y, Allain JP, Fung J, et al. Transmissibility of hepatitis B virus (HBV) infection through blood transfusion from blood donors with occult $\mathrm{HBV}$ infection. Clin Infect Dis. 2011;52(5):624-32.

26. $\mathrm{Hu} \mathrm{KQ}$. Occult hepatitis $\mathrm{B}$ virus infection and its clinical implications. J Viral Hepat. 2002;9(4):243-57.

27. Zollner B, Feucht HH, Sterneck M, Schafer H, Rogiers X, Fischer L. Clinical reactivation after liver transplantation with an unusual minor strain of hepatitis B virus in an occult carrier. LiverTranspl. 2006;12(8):1283-9.

28. Hui CK, Cheung WW, Zhang HY, Au WY, Yueng YH, Leung AY, et al. Kinetics and risk of de novo hepatitis $B$ infection in HBsAg-negative patients undergoing cytotoxic chemotherapy. Gastroenterology. 2006;131(1):59-68.

29. Lalazar G, Rund D, Shouval D. Screening, prevention and treatment of viral hepatitis B reactivation in patients with haematological malignancies. Br J Haematol. 2007;136(5):699712 .

30. Schnepf N, Sellier P, Bendenoun M, Zini JM, Sanson-le Pors MJ, Mazeron MC. Reactivation of lamivudine-resistant occult hepatitis B in an HIV-infected patient undergoing cytotoxic chemotherapy. J Clin Virol. 2007;39(1):48-50.

31. Imamura T, Yokosuka O, Chiba T, Kanda T, Kojima H, Fukai $\mathrm{K}$, et al. Lamivudine treatment in a patient with hepatitis $\mathrm{B}$ virus reactivation after allogenic peripheral bone marrow transplantation. Leuk Lymphoma. 2005;46(6):915-7.

32. Fukuda R, Ishimura N, Niigaki M, Hamamoto S, Satoh S, Tanaka S, et al. Serologically silent hepatitis B virus coinfection in patients with hepatitis $C$ virus-associated chronic liver disease: Clinical and virological significance. J Med Virol. 1999;58(3):201-7.
33. Arababadi MK, Hassanshahi G, Yousefi H, Zarandi ER, Moradi M, Mahmoodi M. No detected hepatitis B virus-DNA in thalassemic patients infected by hepatitis $C$ virus in Kerman province of Iran. PakJ Biol Sci. 2008;11(13):1738-41.

34. Arababadi MK, Hassanshahi G, Yousefi H. HBV-DNA in hemodialysis patients infected by HCV. Saudi J Kidney Dis Transpl. 2009;20(3):398-401.

35. Torbenson M, Kannangai R, Astemborski J, Strathdee SA, Vlahov $D$, Thomas DL. High prevalence of occult hepatitis B in Baltimore injection drug users. Hepatology. 2004;39(1):51-7.

36. Toyoda H, Hayashi K, Murakami Y, Honda T, Katano Y, Nakano I, et al. Prevalence and clinical implications of occult hepatitis B viral infection in hemophilia patients in Japan. J Med Virol. 2004;73(2):195-9.

37. Candotti D, Grabarczyk P, Ghiazza P, Roig R, Casamitjana N, Iudicone $\mathrm{P}$, et al. Characterization of occult hepatitis $\mathrm{B}$ virus from blood donors carrying genotype A2 or genotype D strains. J Hepatol. 2008;49(4):537-47.

38. Arababadi MK, Mohammadzadeh A, Ahmadabadi BN, Pourfathollah AA, Kennedy D. Polymorphisms within Fas gene are not associated with occult hepatitis B virus infection. Hepat Mon. 2011;11(1):23-6.

39. Behzad-Behbahani A, Mafi-Nejad A, Tabei SZ, Lankarani KB, Torab A, Moaddeb A. Anti-HBc \& HBV-DNA detection in blood donors negative for hepatitis $B$ virus surface antigen in reducing risk of transfusion associated $\mathrm{HBV}$ infection. Indian J Med Res. 2006;123(1):37-42.

40. Amini KS, Talebian A, Moghtadaie M, Ranjbar KF, Ferdowsian F, Samie S. Detection of hepatitis B virus DNA (PCR) in HBsAg negative, anti-HBc positive blood donors in Tehran province. Blood J. 2004;3:379-87.

41. Song EY, Yun YM, Park MH, Seo DH. Prevalence of occult hepatitis $B$ virus infection in a general adult population in Korea. Intervirology. 2009;52(2):57-62.

42. Sharifi-Mood B, Sanei-Moghaddam E, Ghasem-Zadeh I, Khosravi S. Occult hepatitis B virus infection among anti-HBc only positive individuals in the Southeast of Iran in high prevalence of HBV infection region. Iran Red Crescent Med J. 2009;11(1):90-2.

43. Jafarzadeh A, Arababadi MK, Mirzaeem M, Pourazar A. Occult hepatitis B virus infection among blood donors with antibodies to hepatitis B core antigen. Acta Med Iran. 2008;46:27-32.

44. Arababadi MK, Pourfathollah AA, Jafarzadeh A, Hassanshahi G. Serum levels of Interleukin (IL)-10 and IL-17A in occult HBV infected south-east Iranian patients. Hepat Mon. 2010;10(1):31-5.

45. Soejima Y, Ikegami T, Taketomi A, Yoshizumi T, Uchiyama H, Harada N, et al. Hepatitis B vaccination after living donor liver transplantation. Liver Int. 2007;27(7):977-82.

46. Dhawan HK, Marwaha N, Sharma RR, Chawla Y, Thakral B, Saluja $\mathrm{K}$, et al. Anti-HBc screening in Indian blood donors: still an unresolved issue. World J Gastroenterol. 2008;14(34):5327-30.

47. Pourazar A, Salehi M, Jafarzadeh A, Arababadi M, Oreizi F, Shariatinezhad K. Detection of HBV DNA in HBsAg Negative Normal Blood Donors. Iran J Immun. 2005;2(3):172-6.

48. Abdi J, Moazami GR. Prevalence of HBcAb among the HBsAg negative first-time blood donors in Khorramabad and Borujerd blood centers. Blood J. 2007;4:323-9.

49. Dragun D. Humoral responses directed against nonhuman leukocyte antigens in solid-organ transplantation. Transplantation. 2008;86(8):1019-25.

50. McFarlane H. Immunoglobulins in Populations of Subtropical and Tropical Countries. In: Oscar B, Latner AL, editors. Advances in Clinical Chemistry: Elsevier; 1973. p.153-238.

51. Garcia-Montalvo BM, Farfan-Ale JA, Acosta-Viana KY, PuertoManzano FI. Hepatitis B virus DNA in blood donors with anti$\mathrm{HBC}$ as a possible indicator of active hepatitis B virus infection in Yucatan, Mexico. Transfus Med. 2005;15(5):371-8.

52. Kaminski G, Alnaqdy A, Al-Belushi I, Nograles J, Al-Dhahry SH. Evidence of occult hepatitis B virus infection among Omani blood donors: a preliminary study. Med Princ Pract. 2006;15(5):368-72.

53. Silva CM, Costi C, Costa C, Michelon C, Oravec R, Ramos AB, et al. Low rate of occult hepatitis B virus infection among anti-HBc positive blood donors living in a low prevalence region in Brazil. J Infect. 2005;51(1):24-9. 